Acta vet. scand. $1977,18,561-562$.

Brief Communication

\title{
SPECIES SPECIFICITY IN THERMOSTABLE AND ETHANOL INSOLUBLE TISSUE ANTIGENS *
}

\section{FURTHER IMMUNIZATION OF RUMINANTS WITH ANTIGENS FROM OTHER RUMINANTS AND WHALE (BALAENOPTERA ACUTOROSTRATA)}

In a previous experiment, it was shown that goats developed species specific antibodies against antigen from bovine kidney prepared by boiling and ethanol precipitation (BE) (Andersen 1975). The experiment indicated that ruminant species might be able to produce species specific antibodies towards BE antigens from other ruminant species. The following experiments were undertaken in order to test the validity of this supposition.

Eighteen goats were inoculated with BE kidney and spleen from sheep, reindeer, European moose as well as BE kidney from the little piked whale (Balaenoptera acutorostrata). Six sheep were inoculated with BE kidney and spleen from goat. All the antigens mentioned were inoculated on 2 or 4 animals. The methods described previously (Andersen) were followed, and the experimental period was $14-15$ months. The whale antigen was included in the experiment because the meat of this species is used as food, and because it is difficult to detect the irregular admixture of whale meat to meat from ruminant species.

The antiwhale reaction developed quite rapidly and was species specific. Two goats inoculated with BE kidney and 2 goats with BE spleen from European moose also developed species specific antibodies. Animals immunized with $\mathrm{BE}$ antigens from goat, sheep and reindeer did not produce detectable amounts of antibodies, with the exception of 1 goat.

Antibodies against homologous antigen-first appeared in the serum from this goat, which was immunized with ovine $B E$ kidney antigen. This reaction then weakened and the serum finally reacted against caprine $\mathrm{BE}$ kidney preparation. When this reaction was observed, the urine of the animal was examined and haematuria and proteinuria were demonstrated. The animal

\footnotetext{
* Supported by the Agricultural Research Council of Norway.
} 
had always appeared to be in normal state of health during the course of the experiment. Studies of serum and kidney from this animal were performed and will be presented separately.

The experiment showed that as far as the particular antigens used in this study are concerned, the ability of small ruminants to produce antibodies varies. This is probably dependent upon the extent of interspecies relationships.

Arne E. Andersen

The Department of Forensic Medicine and

The Department of Microbiology and Immunology, Veterinary College of Norway, Oslo.

\section{REFERENCE}

Andersen, A. E.: Species specificity in thermostable and ethanol insoluble tissue antigens. I. Immunization of rabbits and goats with bovine antigen. Acta vet. scand. 1975, 16, 251—257.

(Received September 8, 1977).

Reprints may be requested from: Arne E. Andersen, the Department of Forensic Medicine, Veterinary College of Norway, P.O. Box 8146, Oslo Dep., Oslo 1, Norway. 